\title{
Kentsel Mekanın Değişimi ve Gelişme Döngüleri; Eski Keresteciler Çarşısı (İzmir) Örneği
}

\author{
Change of Urben Space and Redevelopment Cycle; Eski Keresteciler \\ Carsisi (Izmir) Case Study
}

\section{Seda Sakar Atçeken}

Mersin Üniversitesi, Şehir ve Bölge Planlama Bölümü, Mersin

\section{ÖZ}

Kentler, kuruldukları günden itibaren politik, coğrafi, beşerî, ekonomik değişkenlerin etkisiyle biçimlenen dinamik oluşumlardır. Gelişen bilgi ve teknolojinin sağladığı imkanlarla, modern üslup ve biçimlerde şekillenen tasarımların kentsel alanlarda görülmeye başlaması, kentlerin dinamik yapısına daha da hız kazandırmıştır. Ancak mevcut kentsel doku ve yapılaşma biçimlerinden bağımsız olarak üretilen bu tasarımlar sonucunda, kentsel çevrelerin özgün ögeleri kaybolmaya, yeni üretilen kent parçaları aynılaşmaya ve standartlaşmaya başlamıştır. Buna rağmen insan ve doğal çevrenin etkileşiminden meydana gelen kentler, farklı toplumsal ihtiyaçlar ve bu ihtiyaçların gerektirdiği mekânsal organizasyonlar sonucunda farklılaşmaktadır. Kentsel mekânın biçimlenmesinde en önemli değişken olan kullanıcının, sahip olduğu değerleri kentsel dokuya aktarması ve özgün ögeler kazandırması ise tarihsel bir sürecin sonucudur. $\mathrm{Bu}$ bağlamda kent dokusunun hangi süreçlerden geçerek farklılaştığı ve bu süreçlerin nasıl bir çözümleme ile ortaya koyulacağı sorusu ortaya çıkmaktadır. Kentsel karakterin tanımı ve tarihselliği üzerine teorik ve metodolojik bir çerçeve sunmayı amaçlayan bu çalışmada, kentsel mekânın değişimi tartışılacaktır. Çalışmanın yöntem bölümünde kentsel mekânın değişim süreçlerini analiz etmeyi sağlayan kentsel morfoloji bilimi ve Conzen tarafından geliştirilen "gelişme döngüleri” ele alınacaktır. Şehirlerde farklı dönemlere ait özgün değerlerin görüldüğü ve tarihsel bir sürecin ürünü olan en önemli alanlar olan tarihi kent merkezleri, araştırmanın teorik çerçevesi açısından önemlidir. Eski Keresteciler Çarşısı (İzmir) örnek alanında gerçekleştirilen bu çalışmanın, benzer alanlarda yürütülecek araştırmalar için yol gösterici olması amaçlanmaktadır.

Anahtar sözcükler: Gelişme döngüsü; kentsel morfoloji; mekanın değişimi.

\begin{abstract}
Cities are dynamic formations that have been formed by the effects of political, geographical, human and economic variables. The appearance of designs shaped by the developing information and technology in modern styles and forms in urban areas has accelerated the dynamic structure of cities even more. However, as a result of these designs which are produced independently of the existing urban forms, the original elements of the urban environments have started to disappear. Nevertheless, cities, which are formed by the interaction between human and natural environment, differ as a result of different social needs and the spatial organizations. The user transfers his/ her values to the space and gains original elements in historical process. In this context, the question of which processes the urban fabric differs through and how these processes will be presented emerges. In this study, which aims to present a theoretical and methodological framework on the definition and historicity of urban character, the change of urban space will be discussed. In the methodology section of the research, urban morphology which enables to analyze the formation processes of urban space, and the "redevelopment cycle" developed by Conzen will be discussed. Historic city centers, which are the most important areas where unique values of different periods are observed in cities and the products of a historical process, are important in terms of the theoretical framework of the research. This study, which is carried out in Eski Keresteciler Çarşısı (Izmir), is intended to be a guide for researchers in similar studies.
\end{abstract}

Keywords: Redevelopment cycle; urban morphology; change of space.

Geliş tarihi: 25.01 .2021 Kabul tarihi: 05.05.202I

Online yayımlanma tarihi: 26.05.202I

Illetişim: Seda Sakar Atçeken

e-posta: iytesedasakar@yahoo.com 


\section{Giriş}

Doğal sistemler ve insan topluluklarının mekânsal bütünleşmesini temsil eden, zamanla insanın ihtiyaçları (çalışma, barınma, eğlenme ve dinlenme gibi gereksinimler sonucunda) çerçevesinde değişmiş ve gelişmiş sistemler olarak tanımlanabilen kentler; kullanıcılarının mekâna dair beklentilerinin ve müdahalelerinin toplumsal yapıyı meydana getiren unsurların farklılaşması sonucu şekillenmekte olup, kendilerine biçilmiş bir kurgunun parçası olamayacak kadar hızlı değişmektedirler. Gelişen teknolojinin etkisiyle farklı toplumlar ve kültürler arasındaki mesafelerin azalması ve sınırların ortadan kalkması ile yalnızca sosyal yapıyı meydana getiren özgünlükler değil, kentsel yapıyı meydana getiren mekânsal ögeler de aynılaşmaktadır. Her ne kadar "popüler kültür (hızlı üretilen ve hızıı tüketilen kültürel ögelerin bütünü- TDK)" kavramı sosyal ve mekânsal yapının belirleyici bir ögesi haline gelse de hâlâ kent mekânını fiziksel olarak şekillendiren toplumun yaşanmışlıklarını barındıran, coğrafyanın ve doğal yapının izlerini taşıyan özgün ögeleri barındırmaktadır. Conzen' e (Whitehand, 198I, s. 80) göre kent, yakın yaşam alanıdır ve morfolojisini toplumun işlevsel gereksinimlerine borçludur. Kropf' a (20I4) göre ise kentlerin şekillenmesinde toplumsal hareketler, tarihsel olaylar, din, etnik yapı, coğrafya, doğal yapı, nüfus gibi pek çok unsur sıralanabilir. Kullanıcının geçmiş ve gelenekleri ile olan bağını koparmak istemediğine dikkat çeken Alexander (1965), fiziksel bir mekânın sosyal ilişkiler ile kendine özgü bir anlam kazandığına dikkat çekmektedir. Kullanıcı yaşadığı çevreyi deneyimlerken, sahip olduğu tecrübe ve birikimleri kente işleyerek fiziksel çevreye bir anlam ve karakter kazandırmaktadır. İhtiyaç duyulan gereksinimlerin zamanla değişmesi; tasarlanan formların, işlevlerinin ve bir araya geliş biçimlerinin de değişmesine neden olmaktadır. Bu bağlamda kenti, kullanıcısıyla bütün, fiziksel bir değişim ve dönüşüm süreci olarak ele almak yerinde olacaktır. Toplumsal ihtiyaçlara bağlı olarak meydana gelen bu değişim kentsel dokuya yansımakta ve mekânda biçimsel olarak kendini göstermektedir. Bu kabulden yola çıkarak değişen ihtiyaçlar çerçevesinde biçimlenen mevcut kent formunun hangi süreçlerden geçerek mevcut halini aldığı ve bu süreçleri ortaya koymayı sağlayan bir çözümlemenin nasıl yapılacağı soruları araştırmanın temel çerçevesini oluşturmaktadır. Her ne kadar mekânı meydana getiren bileşenler, modern çağda aynılaşmaya başlasa da değişim ve biçimlenme süreçleri, yerin kendine özgü dinamikleriyle şekillenerek özgünleşmektedir. Kent dokusunda meydana gelen değişim ve biçimlenme süreçlerini göz önüne alarak mekânsal bir çözümlemenin nasıl yapılacağını cevaplamaya çalışan araştırmanın yöntem bölümünde, mekânın değişimini farklı dönemlerde analiz etmeyi amaçlayan kentsel morfoloji ve morfogenetik yöntem yaklaşımları ele alınacaktır. Conzen, farklı dönemlerde insan çabası ve başarısının sürekliliği, formların çeşitliliği ve gelenekselliği, zamanın derinliği ve perspektifi ile bireyin kendi sosyal varlığının bilincine kattığı grup destekli süreklilik duygusuyla; bireyinki kadar sosyal zihnin de somut olarak kök salmasını sağlayan tarihi kent merkezlerinin, farklı dönemlere ait izleri bünyesinde barındırması ve tarihselliği nedeniyle mekânsal değişimin gözlemlenebileceği ögeleri barındırdı̆̆ını savunmaktadır (Whitehand, I98I, s. 84). İzmir - Kemeraltı Tarihi Kent Merkezi - Eski Keresteciler Çarşısı örnek alanında yürütülecek çalışmanın, kent formunda meydana gelen değişimin çözümlenmesine yönelik benzer araştırmalarda yol gösterici olması amaçlanmaktadır.

\section{Kentsel Karakterin Ele Alınış Biçimi ve Tarihsellik}

Antik Roma'daki bir inanışa göre bağımsız ve özgür olan her şey kendine ait bir "gözeten ruh (genius)" sahibidir; doğumlarından ölümlerine kadar insanlara ve yerlere anlam katar, onların karakterini belirler (Norberg-Schulz, 1979, s. 18). Tıpkı insanlar gibi kentler de birbirinden farklı fiziksel özelliklere ve karaktere sahiptirler. Farklı kullanıcı grupları tarafından farkIı eylemleri gerçekleştirmek amacıyla kullanılan ve biçimsel olarak farklı niteliklere sahip, fiziksel ilişkiler sisteminin birlikteliğinden doğan, üç boyutlu geometriye sahip algısal bir gerçeklik olan "mekân” kavramı; ancak ve ancak mekânı anlamlandıran karakter ile birleşerek, kullanıcıda aidiyet hissine karşılık gelen, kendine ait bir ruha sahip duyusal bir olgu olan "yer" kavramına dönüşmektedir (Norberg-Schulz, 1979, s. II). Rossi (1984, s. 103), "yer (the locus)” kavramını birincisi eşsiz (unique) ve fiziksel, ikincisi ise kentsel bağlam içerisinde anlamlanan, farklı nitelikleri ile özelleşen mekân olmak üzere iki maddede tanımlamaktadır. Rossi' nin tanımından yola çıkarak mekânın karakterini algılamayı sağlayan elemanların fiziksel olduğunu ancak bağlamdan ve anlamdan bağımsız ele alınamayacağını söylemek mümkündür.

Değişen mimarlık ve planlama yaklaşımlarının da etkisiyle yirminci yüzyılın başlamasıyla birlikte, kentsel mekânın üretimi farklılaşmaya başlamıştır. İşlevsel bölgeleme (zooning), standartlaşma, hacimlerin ve ölçeğin algılanabilir mekânlar yaratmaktan uzaklaşması gibi eğilimler; özgünlüklerin, "yer" ile ilişkili özelliklerin ve Rossi'nin belirttiği "eşsiz (unique)" mekânların kaybolmasına ve kentlerin tek tipleşmesine neden olmuştur. 1960'lara gelindiğinde ise kentlerin standartlaşması ve aynılaşmasına yönelik karşı eleştiriler ortaya atılmıştır. Modern kentlerin tarihsel, sosyal ve coğrafi değişkenlerden uzak, düşünülmüş kurgulara dayalı bir yapıya sahip olduğunu belirten Lynch (1960), form ve karakter yönünden düzenli bir dokunun oluşabilmesi için farklılaşmaların gerekli olduğunu savunmaktadır. Modernizmin kentsel mekânda yarattığı değişikliklere yönelik eleştirisini sosyal bağlam üzerinden yapan Jacobs (196I) ise kentsel planlama ve tasarımda, kamusal alanların standartlar çerçevesinde formüle edilmesinin yanlış olduğunu; geleneksel planlama anlayışını kullanımları bölgelendirme, önemsizleştirme ve kısıtlama girişiminden ötürü eleştirmekte, yaşayan bir 
"yer" de farklı kullanımların birbirini desteklemesi, devamlılık göstermesi ve farklılıklara sahip olması gerektiğini belirtmektedir. Mekânın tarihsel geçmişi, toleransı ve mevcut eğilimleri analiz edilmeden; güncel mimarlık ve planlama yaklaşımlarının etkisinde kentlere giydirilen kalıpların, ölçüsüz ve rastgele yapılan giysilerden farksız olduğunu savunan Cullen (196I) ise; kentsel çevrenin düzenlenmesinin bir dayatma değil, araştırma ve analizler sonucu çevresel toleranslar çerçevesinde bir yönlendirme olduğunu; kullanıcıya keyifli bir mekân deneyimi sunmaya yönelik tasarımların kentleri daha özgün kılacağını savunmaktadır. Alexander (1965) ise mevcut doku ile ilişki kurmadan üretilen modern çağın cam kuleleri ve beton kütlelerinden oluşan formların, ya tarihsel doku ile uyumsuz olduğu ya da olanın birebir aynısını yapmaktan öteye gidemediğini vurgulamaktadır. Farklı perspektiften bakmalarına rağmen özgün, kullanımların çeşitlendiği, kullanıcıya keyifli bir mekân deneyimi sunan, yaşayan ve en önemlisi aynılaşmak yerine kendine özgü karaktere sahip kentsel dokuların önemine vurgu yapan bu araştırmacıların oluşturdukları kuramsal çerçeveler bugün hâlâ kentsel tasarım yaklaşımlarına kaynak olma özelliği göstermektedir. Araştırmaların bir diğer ortak özelliği ise mekânı objektif bir yaklaşıma dayalı, belirli sistematik çözümlemeler ve bilimsel analizler içeren yöntemler yerine; yöntemlerinin kullanıcı odaklı olması ve kişisel değerlendirmelere dayanması sebebiyle öznel olmalarıdır. Buna karşın kentsel mekânı fiziksel olarak çözümleyerek, kentin ve kent bölgelerinin değişimini tarihsel bir birikimin ürünü olarak bütüncül biçimde analiz etmeye yarayan kentsel morfoloji bilimi; sözü edilen araştırmalarla aynı tarihlerde, 1960'larda Conzen tarafından geliştirilen "kent-plan çözümlemesi (town-plan analysis)" yöntemi başta olmak üzere kent mekânını nesnel olarak ele almaya olanak sağlayacak yöntemler ortaya koymaktadır. Temel kaygının tarihsel ve coğrafi sorgulamalar yoluyla kent formunun analiz edilmesi olduğu ve yalnızca mimari üslupların değil farklı ölçeklerde plan analizlerinin de incelendiği kentsel morfoloji; akademik yazında farklı ekollerden araştırma okulları tarafından kabul görmüştür. Fakat kentsel mekânı bağlam içerisinde değerlendirmesini, kent dokusunun parça-bütün ilişkisi göz önüne alınarak incelenmesini, kullanımlara ve fonksiyonlara önem vererek mekânsal değişimin alt ölçekte ele alınmasını sağlayan İngiltere Okulu tarafından geliştirilen tarihsel-coğrafi yaklaşım, geliştirdiği analiz yöntemleri sebebiyle nesnel değerlendirmelerin gerçekleştirilebilmesi açısından önem taşımaktadır.

Conzen (Whitehand, 198I, s. 80) kent dokusunda meydana gelen ve her biri kendine özgü formlar gerektiren fiziksel çevrenin ve bu çevrede meydana gelen hiçbir değişikliğin rastgele olmadığını, sosyo-ekonomik ve kültürel tarih evrelerine karşılık gelen morfolojik dönemler olarak kendilerini gösterdiklerini savunmaktadır. Yapılı çevrenin tarihsel süreç içerisinde parsel, ada ve sokak örüntüsü ile yapılaşma dokusu ve arazi kullanım durumundaki değişimlerle yeniden üretildiğini belirten Conzen (1960, s. 5), bu değişimler sonucunda kentlerde özgün karaktere sahip alt bölgelerin oluşabileceğini, farklı dönemlerde üretilen yeni örüntüler ile kentsel karakterin değişebileceğini belirtmektedir. Farklı mekânların, karakterlerin ve dokuların birbirinden ayırt edilmesine yönelik fiziksel ölçütler arayarak nesnel analizler içermesi sebebiyle, kentsel tasarım literatüründe yer alan öznel araştırmalardan ayrılan morfogenetik yöntemin temelinde; kentsel dokunun zaman içinde çeşitli süreç ve mekanizmalar ile sürekli bir değişim içinde olduğu ve kentsel karakterin de bu değişim içinde sürekli yeniden üretildiği, dolayısıyla tarihsel olduğu kabulü bulunmaktadır. Bu bağlamda tarihsellik, kentlerin ve dolayısıyla kenti meydana getiren alt bölgeleri oluşturan karakterin oluşumunu etkileyen önemli bir değişkendir.

Kropf (1996, s. 256) tarihselliğin yalnızca bir his ya da soyut bir kavram değil aynı zamanda kullanıcının bilgi birikimi ile algılayabildiği fiziksel bir kavram olduğuna değinmektedir. Fiziksel bileşenler, tarihsel ve kültürel bir birikimi de beraberinde getirerek tarihsel bir özellik kazanmakta; bu tarihsellik kültürel birikim ve toplumsal tecrübeler ile birleşerek "yer" i anlamlandıran, kullanıcının algısı ile yerin sahip olduğu ruhun nesnelleşmesini sağlayan bir olgu olan karakteri meydana getirmektedir (Conzen, 1975, s. 100). Kentsel çevreyi meydana getiren ögeler arasında tarihsellik hissini verenler sadece yapılar değil; aynı zamanda yollar, cepheler, kaplamalar, doku, yapısokak ilişkisi, bahçeler, avlular, meydanlar, anıtsal yapılar vb. ögelerdir. Fakat kullanıcının tarihi hissedebilmesi ve algılayabilmesi için dikkat çeken en önemli ögenin yapılar ve yapı stoku olduğu söylenebilir. Conzen'e göre doğal peyzajın sosyal olarak örgütlenmiş insan tarafından dönüştürülmesiyle meydana gelen, beşerî çaba ve sermayenin yatırımı yoluyla insani isteklerin coğrafi olarak konumlandırılmış maddeye çevirisini temsil eden kentsel formlar zamanla durağanlaşmakta; bu durum zaman içinde biriken formları manzaranın temel morfolojik özelliklerinden biri haline getirmekte ve tarihselleştirmekte$\operatorname{dir}$ (Whitehand, I98I, s. 56). Yapılaşmanın uzun süreli olduğu kentsel alanlarda, farklı dönemlere ait formların ve daha önceki planın izleri kentsel dokuda kalıntılar şeklinde hayatta kalmakta ve buna bağı olarak belirgin tarihsel tabakalaşmaya neden olmaktadır. Bu bağlamda özellikle dokusu ve sokakları, bina tiplerinin çeşitliliği ve dağılımı, özgün dominant ögeleri ile geleneksel formların kendilerine has mekânsal birlikteliğinden meydana gelen tarihsel ve karakteristik ögeleriyle benzersiz yapısı ile kenti meydana getiren diğer parçalarından ayrılan; toplumların kültürel geçmişine yönelik izlerin nesnelleştiği ve bu nesnelleşmenin en iyi gözlemlenebildiği alanlar ise tarihi kent merkezleridir. Kent dokusunda meydana gelen değişimin nasıl oluştuğuna yönelik bir tartışma sürdürmeyi amaçlayan bu çalışma kapsamında, mekânın değişimini içerisinde olduğu bağlam içerisinde ve nesnel analizler yardımıyla değerlendirmeyi sağlayan tarihsel coğrafi yaklaşımın çerçevesinde; sahip olduğu özgün dokusu, tarihselliği ve geçirmiş olduğu değişim süreçleriyle günümüze kadar varlığını sürdüren İzmir-Kemeral- 


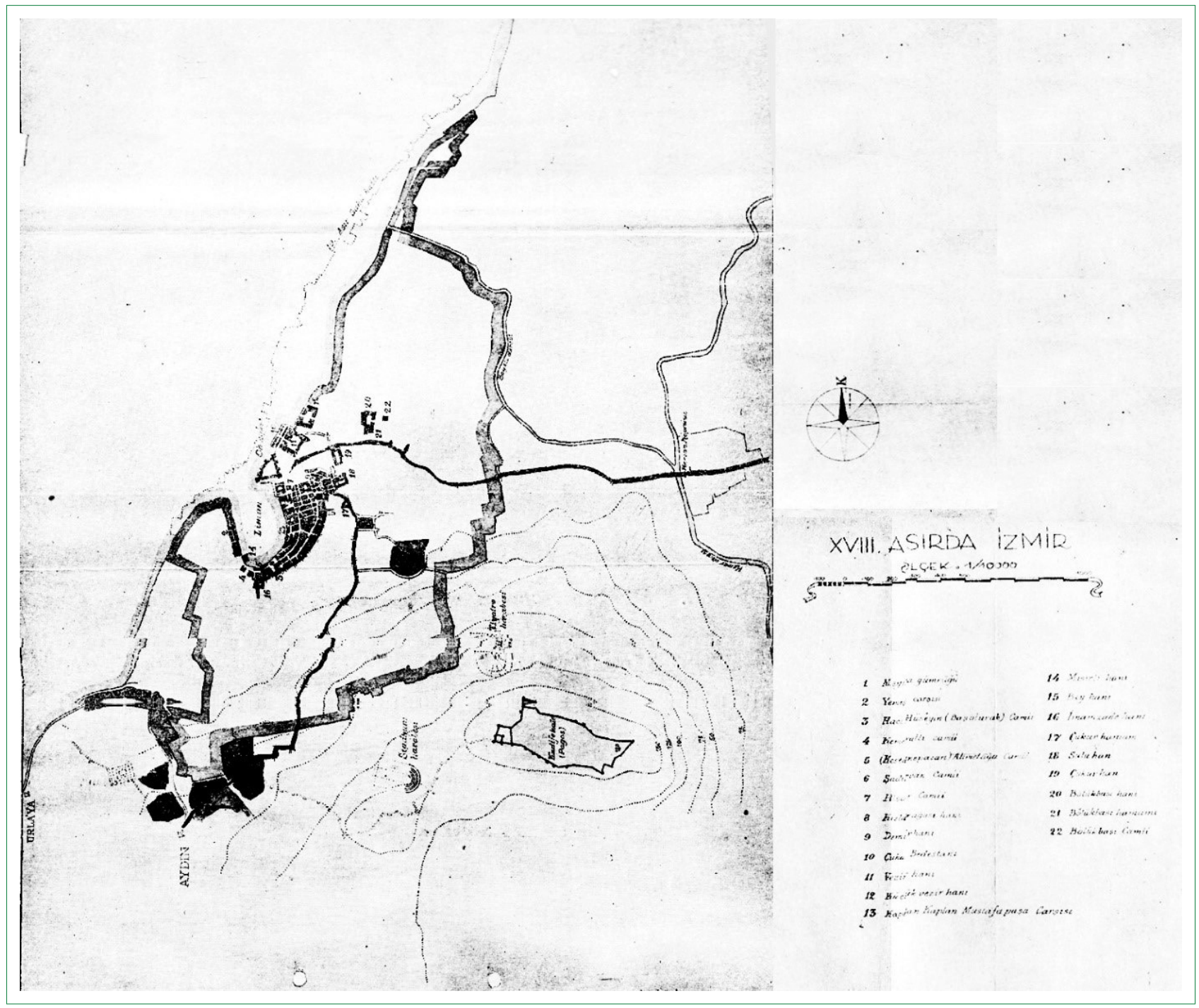

Şekil I. XVIII. yüzyılda İzmir kenti (APiKAM, 20II).

tı Tarihi Kent Merkezi'nde yer alan Eski Keresteciler Çarşısı (87I sokak) örnek çalışma alanı olarak seçilmiştir.

\section{Örnek Çalışma Alanı: İzmir - Kemeraltı}

Kuruldukları dönemden itibaren farklı içsel ve çevresel değişkenler sonucunda kentsel mekânda yer eden özgünlüklerin biriktiği bölgelerin başında gelen tarihi kent merkezleri; kentsel dokuların eskimesi ve yıpranması tartışması ile en çok yüz yüze kalan, kentlerin gelişme dönemlerinde büyük kentsel kullanımlar tarafından çevrelenmiş, tarihsel katmanlaşmanın en fazla olduğu ve karakteristik dokuları ile dikkat çeken bölgelerdir. Kentsel karakterin oluşmasında etkili olan tarihsel katmanlaşma, birikim ve tarihsellik unsurları göz önüne alınarak kent-plan çözümlemesi yaklaşımı çerçevesinde örnek çaIsşma alanı olarak İzmir - Kemeraltı Tarihi Kent Merkezi - Eski Keresteciler Çarşısı seçilmiştir.
M.Ö. 300'lerde Kadifekale ve çevresinde yapılaşmanın başlaması sonucu iç liman olarak kullanılan ve liman arkası faaliyetlerin yer seçtiği Kemeraltı (Şekil I); XVIII. yüzyıla kadar Avrupa'ya hammadde gönderiminin yapıldığı aktif bir ticaret merkezi olmasının yanında tüccarlar tarafından yaşam alanı olarak da kullanılmıştır (Beyru, 20II).

İç liman derinliğinin zamanla azalarak gemiler için elverişsiz hale gelmesi sebebiyle işlevini yitiren ve XVIII. yüzyıl sonlarında tamamen doldurulması sonucunda (Şekil 2); bu günkü Kemeraltı bölgesi ortaya çıkmıştır.

İç liman olarak kullanıldığı dönemde liman arkası faaliyetleri (depo alanları, tamir atölyeleri vb.), konaklama, ticaret, yeme içme kullanımlarının yer seçtiği Kemeraltı'nda liman faaliyetlerinin Punta' ya (Alsancak) taşınmasının ardından kentin eğlence ve kültür faaliyetleri yavaş yavaş yer değiştirmeye; XIX. yüzyılda 


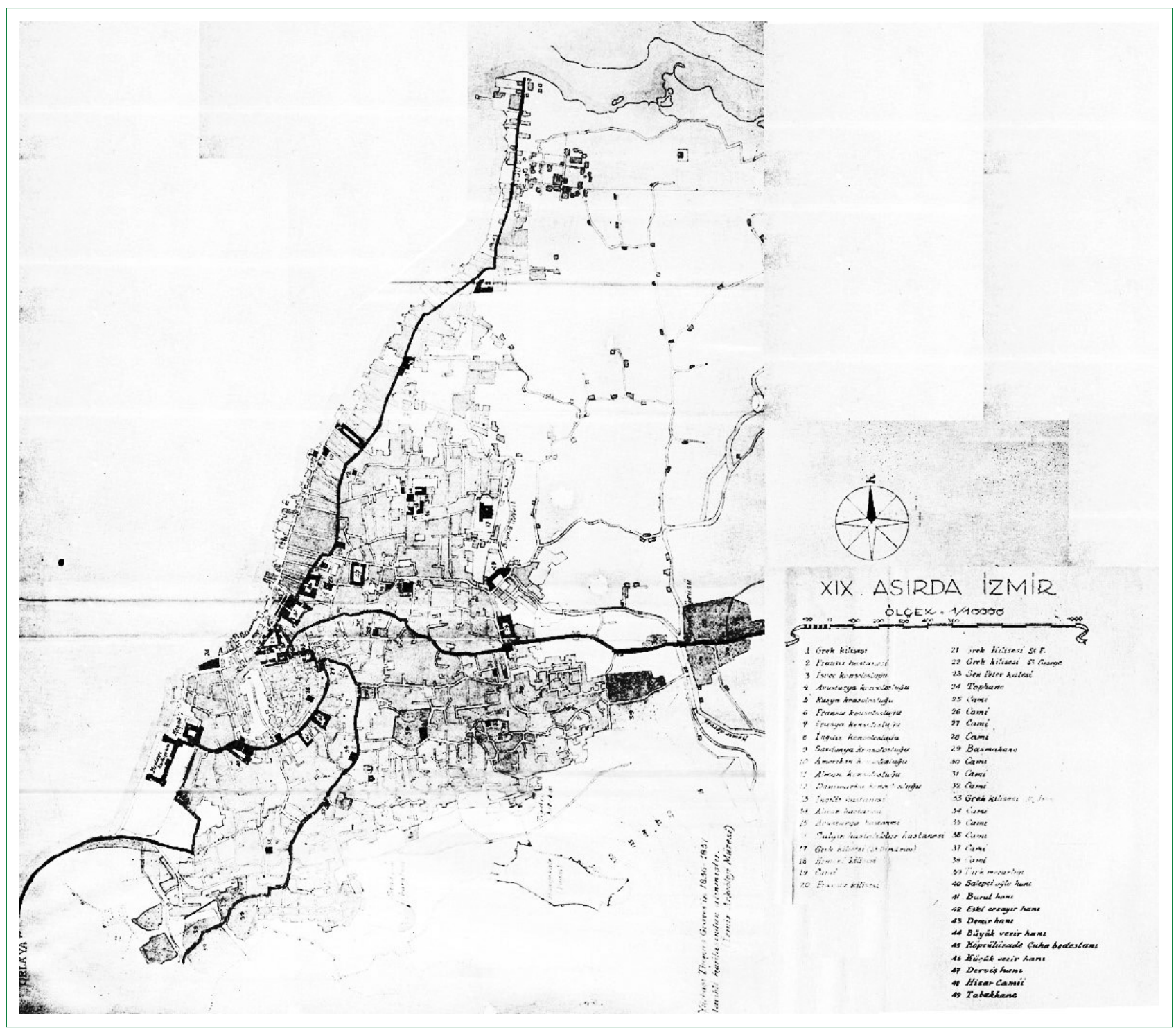

Şekil 2. XIX. yüzyılda İzmir kenti (APIKAM, 20II).

artan demiryolu ve denizyolu ticareti, iç liman yayı içerisindeki yeni yapılaşma alanının meyve kurutma depoları, inşaat işlerine yönelik dükkânlar ve geleneksel sanatlarda uzmanlaşmış bir ticaret bölgesi haline gelmesine neden olmuştur (Beyru, 20I I).

XX. yüzyılın başlarında meydana gelen Punta (Alsancak) yangınının, bu günkü Konak Pier ve Basmane Garı'nı birbirine bağlayan Fevzi Paşa Caddesi'nin kuzeyinde yer alan yaklaşık 300 hektarlık bir alanı yok etmesinin ardından, kentin yeniden imar edilme çalışmalarına başlanmıştır (APIKAM). Yangın sonrası yapılan planlama çalışmaları sonucunda, kentin eski organik dokusu yerine, gridal yapıda bir kentleşme dokusu tasarlanmıştır. Bu gün Kültür Park, Cumhuriyet Meydanı ve Alsancak Tren İstasyonu'nu kapsayan bölgenin tamamı, yangın sonrası yeniden inşa edilen bölgede yer almaktadır. Günümüzde tarihi dokusu ve sahip olduğu turizm potansiyeli sebebiyle hediyelik eşya, yeme-içme faaliyetleri ve kahveciler gibi kullanımların yer seçtiği, konut kullanımından yoksun bir ticaret bölgesi olarak kullanılan tarihi kent merkezinin korunmasına yönelik yaklaşımlar; 1960’lı yıllardan itibaren planlama çalışmalarında yer bulmuş, 2000'li yıllarda üniversitelerin de sürece dâhil olmasıyla hazırlanan Koruma Amaçıı İmar Planıyla çalışmaların kapsamı genişlemiş ve 2012 yılında büyükşehir belediyesi bünyesinde kurulan İzmir Akdeniz Akademisi bünyesinde yürütülen canlandırma çalışmalarıyla çok paydaşı ve katılımcı projeler bünyesinde devam etmektedir.

\section{Araştırma Yöntemi: Tarihsel - Coğrafi Yaklaşım}

Conzen tarafından 1960'larda geliştirilen tarihsel coğrafi yaklaşım kapsamında Londra'nın iki yüz kilometre kuzeybatısında yer alan Ludlow kenti için yapılan analizlerde, eski kent mer- 


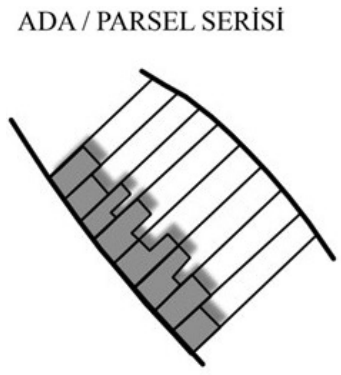

Birikim “Accumulation”

(Toplumsal ihtiyaçlar çerçevesinde mevcut yapıll çevre içerisine eklenen yeni yapilar)

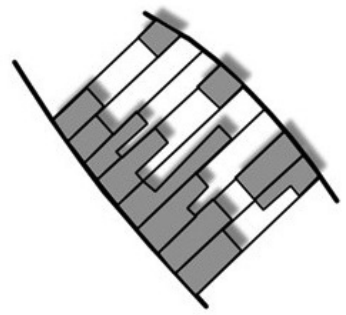

Adaptasyon "Adaptation" (Mevcut yapıların değişen ihtiyaçlar çerçevesinde küçük müdahalelerle yapı ve kullanim olarak değişikliklere uğraması)

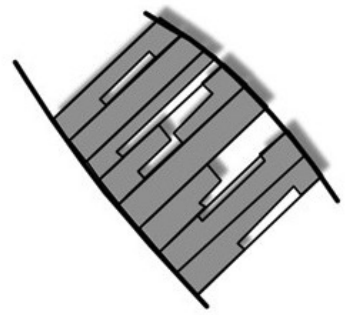

Direnç "Persistence" (Mekânin yeni ihtiyaçlara fiziksel ve fonksiyonel olarak karşılık verememesi)

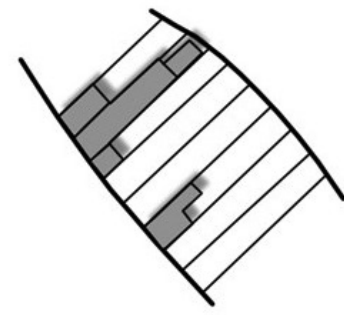

Yerine Geçme "Replacement" (Mevcut yapılarm yıkılarak yerine yeni yapıların inșa edilmesi)

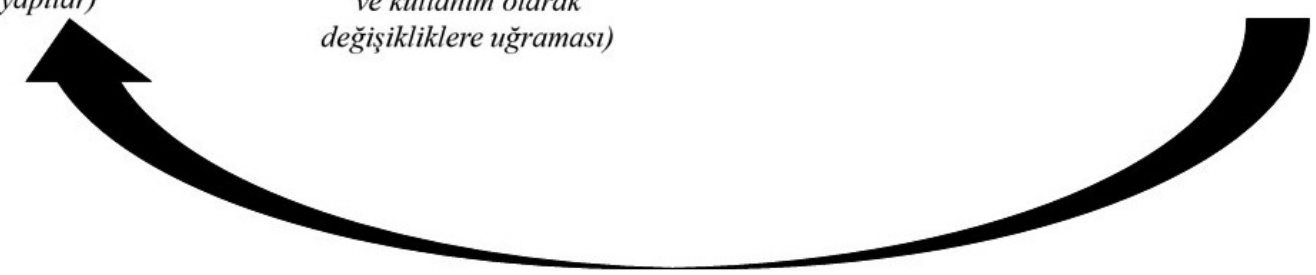

Şekil 3. Conzen tarafından geliştirilen Parsel Gelişme Döngüsü (Larkham ve Jones 1990; s. 69 üzerinden yeniden çizilmiştir).

kezini meydana getiren yapılaşma dokusu ve bina türlerinin doğrudan, arazi kullanım biçiminin ise bireysel unsurları sebebiyle dolaylı olarak tarihsel katmanlaşmaya katkı sağladığı; kent formunu meydana getiren bu üç bileşenin kentsel mekâna dağılımının kendi alansal hiyerarşilerini ürettiği ve bunların üst üste binmesi sonucunda kentsel dokunun morfolojik olarak farklı alt bölgelere ayrıldığı savunulmaktadır. Tek bir yapı adası özelinde ele alınan gelişme döngüsünün tanımlı bir kentsel alanda, her biri gelişme döngüsünün farklı bir evresinde olan; parsel, bina, sokak, cephe, kaplama vb. özellikler bakımından kendi içinde bütüncül ve benzerlikler gösteren, homojen alt bölgelere ayrılmasıyla ortaya çıkan bu alanlara "karakter bölgesi” adı verilmektedir (Conzen, 1988, s. II8).

Kentsel dokuyu meydana getiren tabakaların en başında hiç kuşkusuz kenti çevreleyen, destekleyen ve kendisine bağlı bir sistem haline getiren doğa ve yeryüzü şekilleri yer almaktadır. Bundan sonraki süreçlerin tamamı, fiziksel ögelerin toplumsal gereksinimler sonucunda amaca yönelik değişimini ya da dönüşümünü içermektedir. Fakat bu dönüşüm kendiliğinden ve tesadüfi olmadığı gibi toplumsal gerekliliklerin dinamik yapıs karşısında bir çeşit direnç göstermekte, kent formunu meydana getiren fiziksel ögeler arasında uyumsuzluklara neden olmaktadır. Conzen, önceki tarihsel biçimlerin adaptasyonu ve dönüşümü ya da eski formların yerine yeni formların geçmesine neden olan morfolojik süreçlerin; kentsel dokuyu meydana getiren plan, doku ve kullanımların değişime karşı farkl derecelerde direnç göstermesi nedeniyle daha da karmaşık bir hal aldığını savunmaktadır (Whitehand, 198I, s. 57). Kentse dokuda meydana gelen uyuşmazlıklar sonucunda değişim ve direnç mekanizması üzerinden mekânın biçimlenme sürecinde farklılaşmanın en belirgin hissedildiği yer hiç kuşkusuz kentin üst biçimidir. Bu bağlamda plan düzeyinde kentsel gelişmenin en belirgin olduğu fiziksel yapı da yine kent üst-biçimidir. Kentin üst biçimindeki değişimin nedenleri ve sonuçları ile incelenmesi, kent formunun ne gibi kullanımlarla, hangi dönemlerde ve nasıl geliştiğinin analizi ile çözümlenebilmektedir. Araştırma kapsamında sorulması gereken temel soru ise çalışmanın buraya kadar olan bölümünde bahsedilen değişimin, mekânı deneyimleyen kullanıcının doğrudan algılayabildiği bir ölçekte gerçekleşen değişimin nasıl analiz edilebileceğidir.

Kent mekânı alt ölçekte de üst ölçekte olduğu gibi kullanıcının gereksinimleri doğrultusunda, farklı dönemlerde farklı değişimler göstermektedir. Bu gereksinimlere bağlı olarak ortaya çıkan fiziksel formlar, değişen ihtiyaçlar karşısında az ya da çok dirence sahiptirler. Geliştirdiği kuramsal çerçeveden yola çıkarak ortaya koyduğu morfogenetik yöntem kapsamında, "kent-plan çözümlemesi (town-plan analysis)" ile kentsel yapılı çevredeki değişimlerin incelenmesine yönelik parsel ölçeğinde çalışmalar geliştiren Conzen (1988, s. II7); morfolojik süreçleri birikim (accumulation), adaptasyon (adaptation), direnç (persistence) ve yerine geçme (replacement) olarak tanımlamaktadır (Şekil 3).

Kentsel mekânda morfolojik olarak gözlemlenen ve tabakalaşmanın tek yapı adası özelinde meydana getirdiği ilk evre olan birikim (accumulation), mevcut yapılı çevre içerisine eklemlenen yeni yapıların olduğu evredir. Boş bir parsele inşa edilen yeni yapı, mevcut yapıya eklenen bir bölüm, aynı parselde inşa edilen 


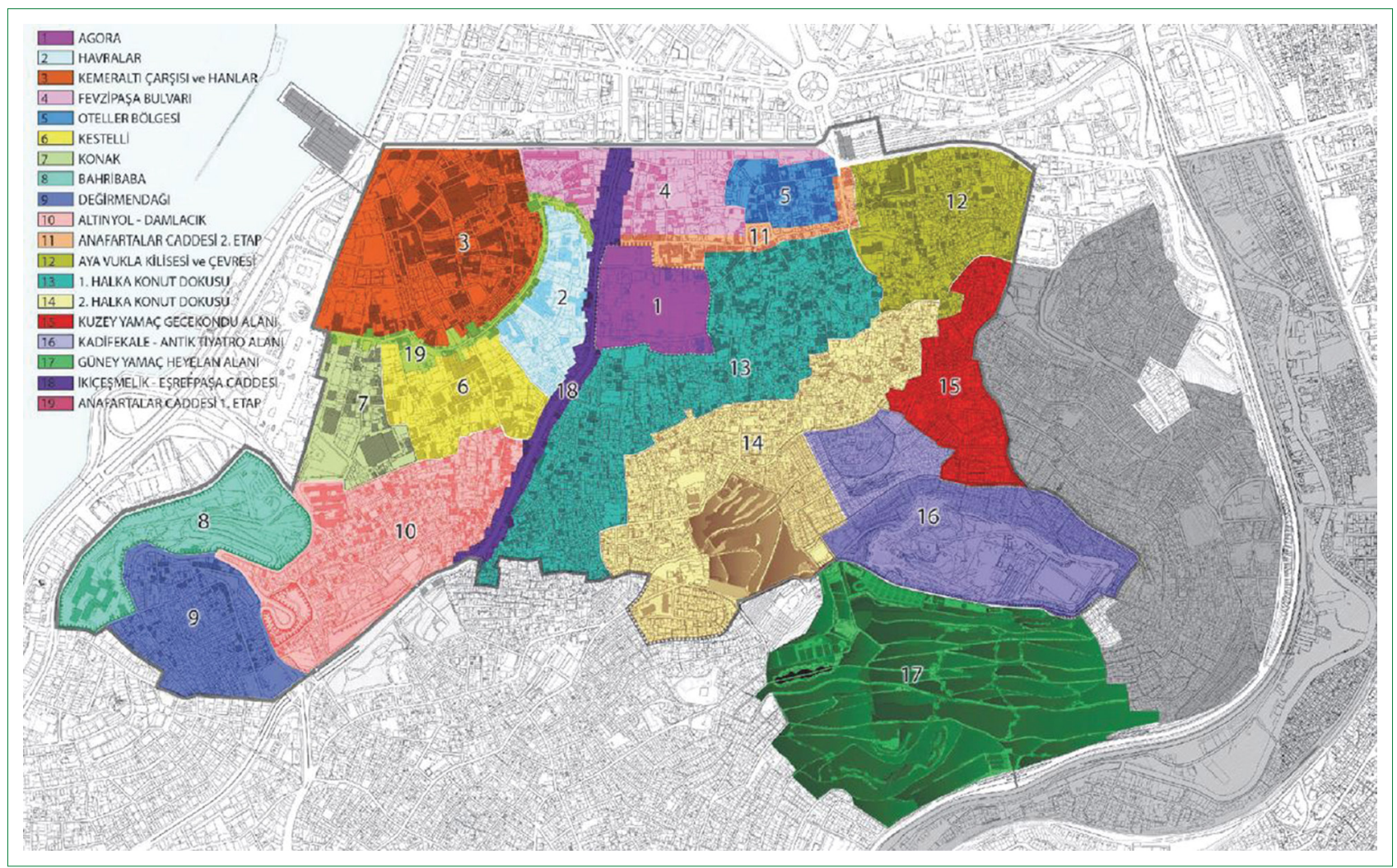

Şekil 4. İzmir Tarih Projesi kapsamında oluşturulan 19 alt bölge (İzmir Tarih Projesi Tasarım Stratejisi Raporu, 20 I7).

ikinci bir yapı ya da ilk parselin bölünerek yeni bir parsel oluşturulması ve oluşan yeni parsele inşa edilen yeni yapı şeklinde gözlemlenebilir. Birikim evresinin sonrasında, var olan formların değişen ihtiyaçlara işlevsel uyum sağlamasını temsil eden ve morfolojik sürecin ikinci evresi olan adaptasyon (adaptation); mevcut yapıların küçük müdahalelerle gerek yapısal gerekse kullanım olarak değişikliklere uğraması şeklinde özetlenebilir. Mekânın yeni ihtiyaçlara fiziksel ve fonksiyonel olarak karşılık verememesinden dolayı ortaya çıkan direnç (persistence) evresi ise; ihtiyaçlara karşılık vermeyen mekânların yıkılmasının ekonomik maliyetleri de beraberinde getirmesinden dolayı eskimeye bırakıldığı ve kent dokusunda hâlâ birikim sürecinin devam ettiği boş alanların bulunduğu üçüncü evredir. İşlevsel adaptasyonun artık tatmin edici olmadığı, yeni fonksiyonun tanımlanmış bir konumda sınırı kaldığı ve fonksiyonel gereksinimlerin baskısının görüldüğü yerlerde ise eski formların yıkılarak yerini yeni formların aldığı bir dönüşüm süreci olan meydana gelmektedir. Dördüncü ve son evre olan bu sürecin adı ise yerine geçme (replacement) sürecidir (Conzen, 1988, s. I19). Buna göre gözlemlenen dört evrenin parsel ölçeğinde döngüsel olarak devam etmesi beklenmekte; döngünün son evresi olan "yerine geçme" evresi, başlayan yeni morfolojik dönem için başlangıç evresi olan "birikim" sürecine karşılık gelmektedir. Birikim, dönüşüm ve yer değiştirmenin kültürel bir ortamdaki dinamik değişiklikleri temsil ettiğini ifade eden Conzen bu süreci "parsel gelişme döngüsü (redevelopment cycle)" olarak adlandırmaktadır (Whitehand,
198I, s. 57). Yerine geçme sürecinin başlamasıyla birlikte, asIında morfolojik süreçlerin ilk evresi olan birikim sürecinin başladığını ve bu süreçlerin döngüsel olarak birbirini takip ettiğini ifade eden Conzen; gelişme döngüsünün yaşandığı evrenin, kent ve kent parçaları için farklılaştığını, bu farklılaşmanın ise kentsel alanda karakteristik alt bölgeler tanımladığını ifade etmektedir.

Çalışmanın buraya kadar olan bölümünde modernleşme dönemi sonrası kentsel mekânın farklı perspektiflerden nasıl ele alındığına yönelik literatür değerlendirmesinde Lynch, Jacobs, Cullen ve Alexander başta olmak üzere kullanıcı tarafından anlam kazanmış, farklı kullanımları ve aktiviteleri barındıran ve her şeyden önemlisi benzerlerinden ayrılan mekanların kendine ait bir karaktere sahip olduğunu savunan araştırmacıların, bu özelliklerin nasıl tespit edileceğine yönelik herhangi bir yöntem ortaya koymadıkları tespit edilmiştir. Buna karşın kentsel mekânı yapı ölçeğinden kentsel ölçeğe doğru sistematik bir biçimde analiz etmeye yarayan; tarihsellik ve tarihsel katmanlaşma ile kurduğu ilişki açısından kent formunu meydana getiren değişimin nasıl çözümleneceğine dair sistematik bir yöntem ortaya koyan kent plan çözümlemesi, mekânın değişimine yönelik bütüncül analizlere dayanması sebebiyle araştırmanın yöntemi açısından önemlidir.

I/5000 Koruma Amaçlı İmar Planı'nda dört alt bölgeye ayrılan İzmir Tarihi Kent Merkezi; 2013 yılında İzmir Büyükşehir Be- 


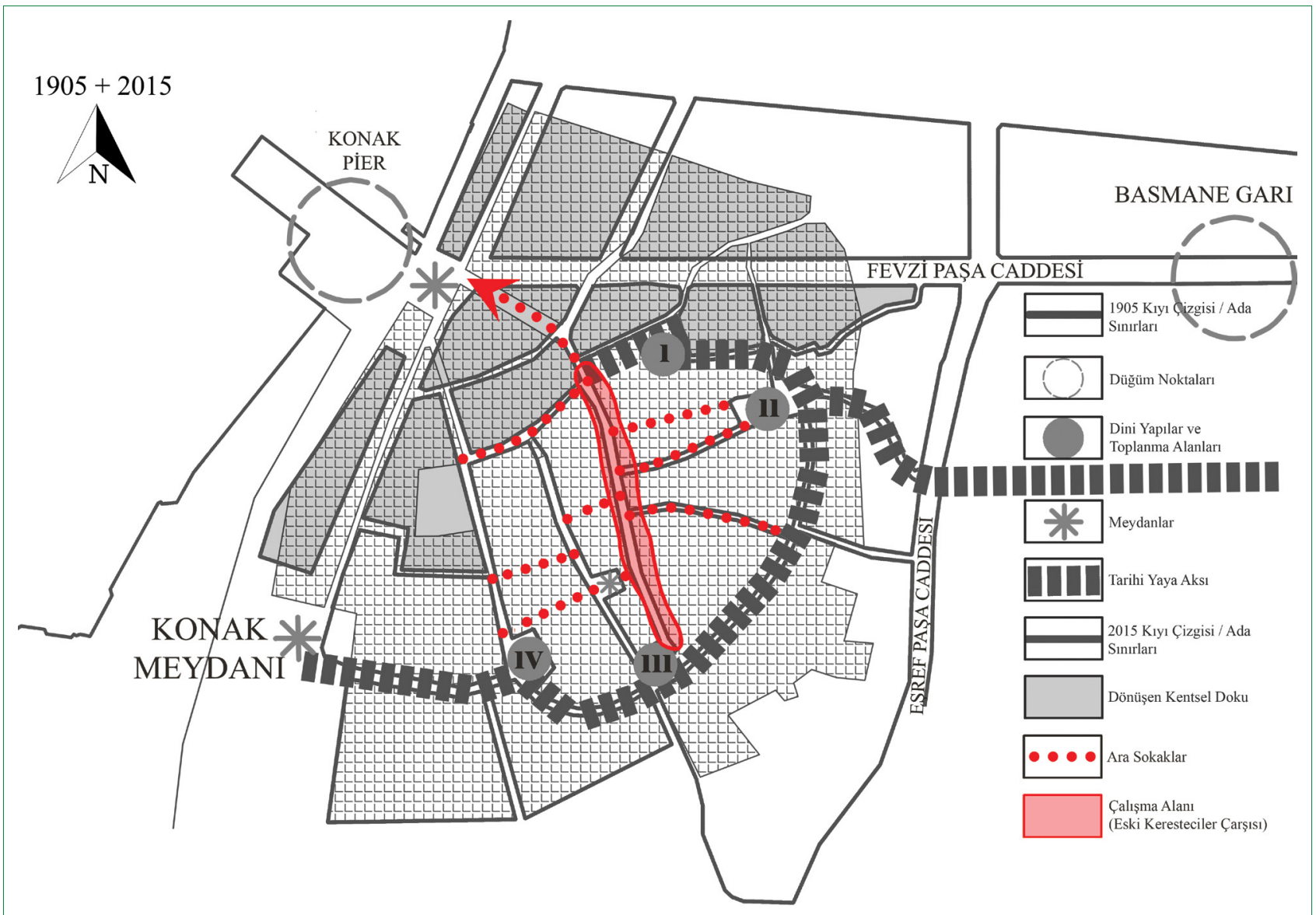

Şekil 5. Kemeraltı Tarihi Kent Merkezi'nde çalışma alanı olarak belirlenen Eski Keresteciler Çarşısı (87। sokak).

lediyesi, İzmir Tarih Projesi kapsamında Burak Belge'nin tarihi merkezi planlama ve koruma politikalarına temel oluşturacak şekilde değerlendirerek zonlara ayıran çalışmasını ve mahalle sınırlarını sentezleyerek 19 alt bölgeye ayrılmıştır (Şekil 4). Bu alt bölgelerden biri olan Kemeraltı Çarşısı ve Hanlar Bölgesi, günümüzde Anafartalar Caddesi'ne karşılık gelen eski iç liman yayının kuzeybatısında yer almaktadır. Merkezden çepere doğru gidildikçe daha genç yapıların gözlemlendiği pek çok tarihi kent merkezinin aksine, kendisini çevreleyen dokudan daha sonra yapılaşmış olması Kemeraltı Tarihi Kent Merkezini, diğer 18 alt bölgeden ayırmaktadır.

Bu nedenle örnek çalışma alanı olarak seçilen İzmir - Kemeraltı Tarihi Kent Merkezi sınırları içerisinde yer alan benzer cephe özellikleri, mimari detay, yapı ölçeği ve bina formuna sahip olması nedeniyle sürekli; tanımlı bir başlangıç ve bitiş noktasına sahip; yapılaşmaya başladığı dönemden itibaren kentsel dönüşüm, kentsel yeniden geliştirme gibi araştırmanın bağlamı dışında herhangi bir tartışmaya konu olmamış olan Eski Keresteciler Çarşısı, kurulduğu dönemde güneyde Başdurak Cami ile başlayıp, tarihi yaya aksının bitiş noktasında bulunan Kızlarağası Hanı ile devam etmekte ve kuzeyde Eski Gümrük Binası (şimdiki Konak Pier) ile sonlanmaktadır. I900'lerin ba- şında kıyı ve Gümrük binası ile sonlanan çarşının Kızlarağası Hanı'nın kuzeyinde kalan kısmı 2015 yılına kadar olan süreçte “dönüşen kentsel doku” kapsamında değişime uğramıştır (Şekil 5). Bu nedenle çalışma alanı Eski Keresteciler Çarşısının kuzeyde tarihi yaya aksının bitiş noktası olan Kızlarağası Hanı ile başlayarak güneyde Başdurak Cami (III) ile biten, karakteristik yapısını günümüze kadar korumuş ve herhangi bir kentsel müdahaleden etkilenmemiş kısmını çevreleyen yapı adaları ile sınırlandırılmıştır (Şekil 5).

\section{Bulgular: Kentsel Mekânın Çözümlenmesi}

Conzen tarafından geliştirilen morfogenetik yöntem kapsamında kentsel bir alanın belirli dönemlerine ait işlevsel ve fiziksel analizler yapılarak, yapısal dokunun ve mekânsal karakterinin incelenmesine "kent-plan çözümlemesi" adı verilmektedir. Bu yöntem kapsamında Conzen (1960, s. 122) kentsel çevrenin hâlihazır (townplan), yapılaşma dokusu (building fabric) ve arazi kullanım durumu (urban land utilization) üzerinden analiz edilerek; fiziksel, ekonomik ve sosyal değişimlerini kapsayan morfolojik süreçleri içerisinde barındıran tarihsel dönemlerin ve mekânsal karakterin analizinin mümkün olduğunu, böylelikle kentsel bir alana yönelik değişimle- 

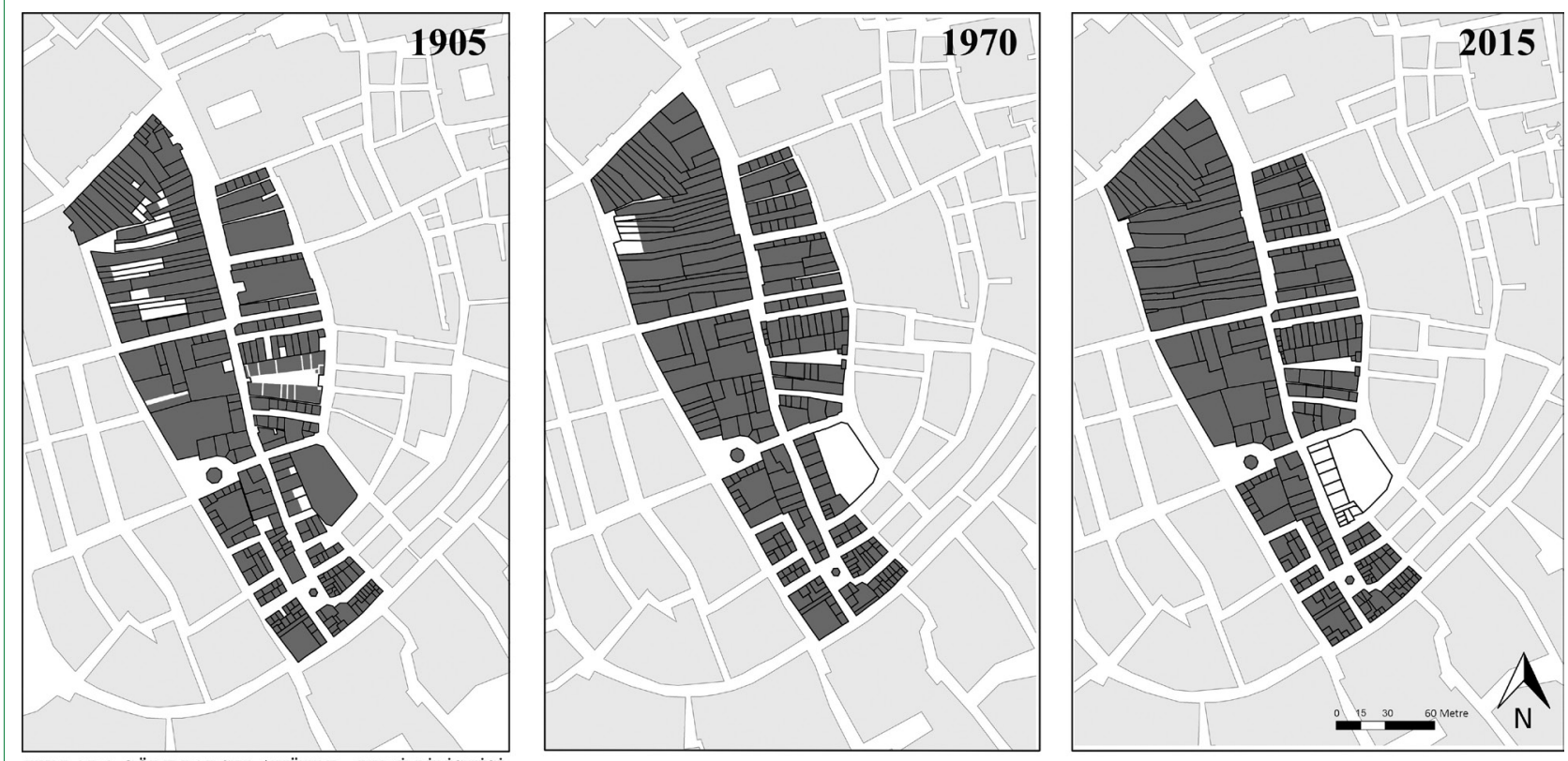

YILLARA GÖRE PARSEL / KÜTLE - ZEMIN ILISKIISI

Şekil 6. İzmir - Kemeraltı tarihi kent merkezi - Eski Keresteciler Çarşısı, yıllara göre parsel kütle - zemin ilişkisi analizi.

rin yaşandığı morfolojik dönemlerin de tespit edilebileceğini savunmaktadır. Tarihsel - coğrafi yaklaşım bağlamında yapılaşma dokusu, bina türleri ve arazi kullanım biçimlerinin, kent formunu meydana getiren bileşenler olduğu kabulüne dayanan bu araştırma kapsamında; mevcut kent formunun hangi süreçlerden geçerek bu günkü halini aldığını ortaya koymayı amaçlayan bir çözümlemenin İzmir - Kemeraltı Tarihi Kent Merkezi - Eski Keresteciler Çarşısı örnek alanında, morfolojik süreçlerin analizi yardımıyla incelenmesi planlanmaktadır.

Belirlenen örnek çalışma alanına ait morfolojik süreçlerin ortaya koyulmasına yönelik bir analiz için gerekli olan hâlihazır, yapılaşma dokusu ve arazi kullanım bilgilerine sahip ilk altık 1905 yılına ait sigorta haritalarıdır. Fransızca aslından çevrilerek yapının fiziksel özelliklerine ait bilgilerin yanı sıra kullanıma yönelik bilgilerin de yer aldığı 1905 yılı haritalarından sonra kentsel mekândaki değişim analizine yönelik detaylı bilgiye sahip elde edilen ilk kaynaklar 1970'li yıllara denk gelmektedir. Tuna (1970) ve Arkon (1978) tarafından hazırlanan analizlerden derlenen bilgiler doğrultusunda değişimin ortaya koyulması amacıyla incelenen ikinci tarihsel dönemin ardından gelen üçüncü ve son dönem çalışmaları ise 2015 yılına ait yerinde incelemelerden oluşmaktadır. Bu kapsamda çalışma alanı için hazırlanan parsel/kütle - zemin ilişkisinin yıllara göre değişimi incelendiğinde (Şekil 6); 1905 yılında alan sınırları içerisinde Han tipi yapıların bulunduğu pek çok büyük parselin yer aldığı ve alanın kuzeydoğusunda yer alan yapı adasındaki parsellerin iç kısımlarda avlulu bir yapıya sahip olduğu görülmektedir. 1970 yılına gelindiğinde han yapılarının bulunduğu parsellerin kendi içlerinde bölünmeye ve alanın kuzeydoğusunda yer alan yapı adasındaki par- sellerin ise dolmaya başladığı gözlenmektedir. 1984 yılında onaylanan Koruma Amaçlı İmar Planı kararları arasında yer alan ilave kat ve tabanda parselin tamamına inşaat yapımına yönelik tanınan haklar sonrası 2015 yılına gelindiğinde parsel örüntüsünde yeniden birleşmelere rastlanmaktadır.

Eski Keresteciler Çarşısı özelinde ele alınan ancak her kentin kendine özgü dokusunda meydana gelen bu değişimler elbette ki tesadüfi değildir. Her dönem kendine özgü izlerini kentsel dokuda bırakır ve bu izler morfolojik bir dönem olarak gözlemlenebilir. Bir morfolojik dönemden diğerine geçerken kentsel dokuyu meydana getiren ögelerden bazıları değişime karşı direnç gösterirken bazıları da adaptasyon ve dönüşüm geçirerek yenilenen mekânsal süreçlere uyum sağlamaktadır. Kentsel dokuda parsel ve bina örüntüsünün değişime gösterdiği direnç fazla iken, kentsel kullanımların gösterdiği direncin daha az olduğu tespit edilmiştir (Conzen, 1975, s. II8). Araştırmanın kavramsal çerçevesinde belirtildiği gibi Conzen tarafından geliştirilen kent-plan çözümlemesi kapsamında yapılan gelişme döngüleri (birikim, adaptasyon, direnç ve yerine geçme) analizinin, örnek çalışma alanı üzerinden gerçekleştirilesiyle kentsel mekânda değişimin çözümlenmesi amaçlanmaktadır.

Gelişme evrelerinden ilki olan birikim (accumulation) süreci, 1905 - 1970 - 2015 dönemleri arasında bölgedeki döngüsünü tamamlamıştır. Tablo I'de çalışma alanının kuzeybatısında yer alan yapı adasındaki parsellerin 1905 döneminde iç kısımlarında yer alan boşlukların, 2015 yılına gelindiğinde tamamen yapılaşarak dolması, gelişme evrelerinden birikim sürecine örnek olarak gösterilebilir. 
Bölgede görülen gelişme evrelerinden bir diğeri adaptasyon (adaptation) sürecidir. Kentsel dokunun değişen toplumsal ihtiyaçlar ve mekânsal kullanımlar doğrultusunda meydana gelen müdahaleler sonucunda işlevsel hale getirilme süreci olan adaptasyon evresinin, özellikle çalışma alanı içerisinde yer alan han yapılarında meydana geldiği gözlemlenmiştir. Tablo 2'deki örnekte 1905 döneminde konaklama faaliyetleri için kullanılan han yapısının, 2015 yılında kullanım değişikliğine uğrayarak perakende ticaret işlevi kazanması ve bunun sonucunda eskiden yapının iç kısmından giriş alan birimlerin, günümüzde birbirinden bağımsız ve sokağa bakan cephelerden giriş alacak şekilde değişime uğradığı görülmektedir. Bu değişiklik sokakla bağlantısı olmayan iç kısımdaki birimlerin âtıl kalmasına ve yapılan fiziksel müdahaleler sonucunda eskiden bölgenin karakteristik ögelerinden biri olan han yapısının günümüzde tescilli yapılar arasında yer alamamasına neden olmuştur.

Bölgenin tarihsel yapısı ve kentsel dokusu göz önüne alındığında, çalışma alanı sınırları içerisinde varlığını devam ettirmeye çalışan pek çok tescilli yapıya rastlanmaktadır. Bu bağlamda morfolojik süreçlerden üçüncüsü olan direnç (persistence) evresi, bölgenin tamamında adaptasyon evresi ile iç içe geçmiş bir şekilde gözlenmektedir. Yeni ihtiyaçlara fonksiyonel olarak karşılık veremediği gibi fiziksel adaptasyonların da maddi olarak karşılanamadığı pek çok yapı, çökme ya da yıkılma tehlikesine rağmen kullanılmaya devam edilmektedir. Analizler kapsamında "direnç" evresinde olan parseller, yalnızca restorasyon ya da yerine geçme maliyetlerinin fazla olması sebebiyle eskimeye bırakılan değil, artık herhangi bir kullanımın da olmadığı tekil yapılar olarak kabul edilmiştir.

Conzen tarafından kentsel gelişme döngüsü içinde son evre olarak kabul edilen yerine geçme (replacement) evresinin özellikle alansal büyüklüğü fazla olan parsellerde meydana geldiği görülmektedir. Tablo 3'te 1905 döneminde han yapısının yer aldığı parselin, 2015 yılında yıkıı yeniden inşa edilerek yerine bölgenin karakteristik yapısı ile uyumsuz iş hanı yapısının inşa edildiği görülmektedir.

Araştırmanın buraya kadar olan kısmında ele alınan temsili örneklerin, çalışma alanı sınırları içerisinde gözlemlenen morfolojik süreçleri açıklamak amacıyla bölgenin tamamında yapılması, belirlenen yöntem kapsamında sağııklı bir tartışmanın yürütülmesi açısından önem taşımaktadır.

\section{Tartışma: Kentsel Mekânda Değişimin Çözümlenmesi}

Conzen'e göre morfolojik süreçlerin (birikim, adaptasyon, direnç ve yerine geçme) eş zamanlı çalışması sonucunda kentsel doku, dinamik ve bölgesel bir yapı kazanmakta; buna bağlı olarak formun görece kalıcılığı ve temsil ettiği dönemler arasındaki ilişki, yerel toplum tarafından kentsel
Tablo I. Eski Keresteciler Çarşısı'nda “Birikim” süreci örneği

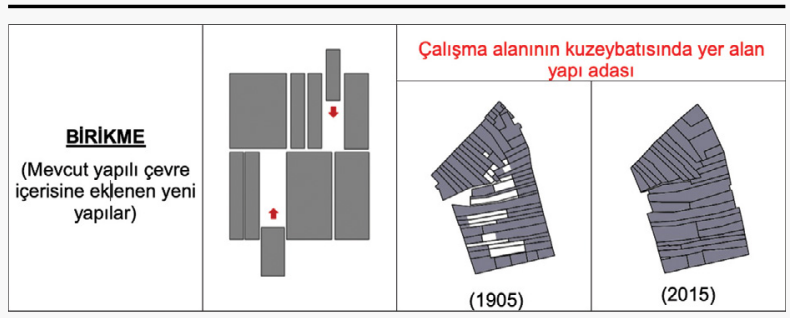

Tablo 2. Eski Keresteciler Çarşısı'nda "Adaptasyon" süreci örneği

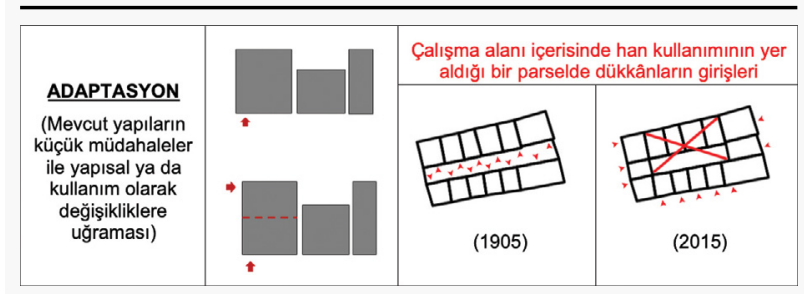

Tablo 3. Eski Keresteciler Çarşısı'nda "Yerine Geçme" süreci örneği

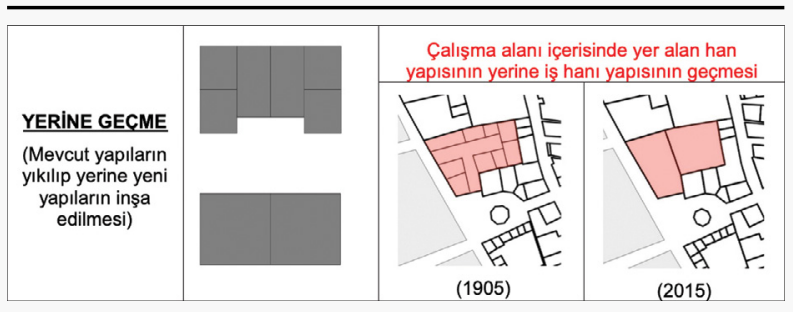

dokunun yaratılması ve dönüştürülmesi sürecindeki sürekli değişiklikleri vurgulamaktadır (Whitehand, 198I). Kentsel doku ve kentsel dokudan biraz daha az bir ölçüde yapı dokusu, geçmiş döneme ait sermaye yatırımları ve arazi mülkiyetlerini yansıtma eğiliminde oldukları için daha stabilken, arazi kullanımı ise değişen işlevsel dürtülere daha kolay tepki vermesi sebebiyle tarihsel değere sahip kentsel doku üzerindeki etkisi daha dinamiktir. Temel amacı mevcut kent formunun bu günkü halini alıncaya kadar geçtiği süreçlerin, nasıl ve hangi yöntemlerle çözümlenebileceğini tartışmak olan bu araştırmada; kentsel mekânın değişimini farklı dönemlerde analiz etmeyi sağlayan kentsel morfoloji ve kent-plan çözümlemesi yöntemleri kapsamında morfolojik süreçler ele alınmıştır.

İzmir - Kemeraltı Tarihi Kent Merkezi - Eski Keresteciler Çarşısı örnek alanında gerçekleştirilen morfolojik süreçlerin analizine yönelik incelemeler sonucunda; her ne kadar ilk bakışta tanımlı bir başlangıç ve bitiş noktasına sahip, yapIsal özellikleri sebebiyle özgün bir karaktere sahip, bütün bir sokak gibi görünmesine rağmen kendi içerisinde farklı alt 


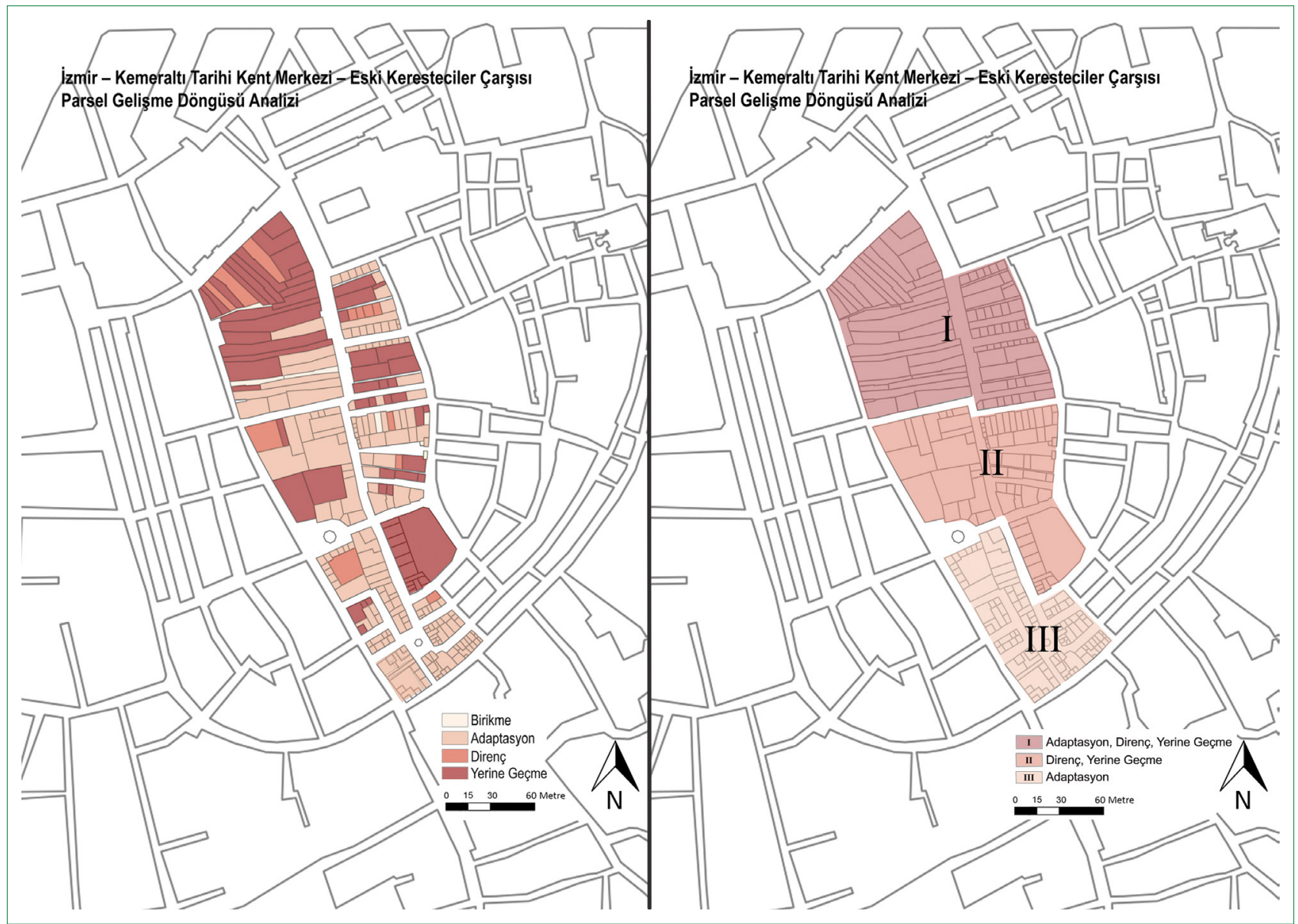

Şekil 7. İzmir Kemeraltı tarihi kent merkezi - Eski Keresteciler Çarşııı Parsel Gelişme Döngüsü Analizi.

bölgelerden meydana geldiği tespit edilmiştir. Şekil 7'de (sağda) sokağın kuzeyinde yer alan "l” numaralı bölgenin, 1905 yılından günümüze kadar olan süreçte önce liman arkasında yer alan depo faaliyetleri için kullanıldığı ancak daha sonra değişen kullanımlar nedeniyle yerine geçme süreçlerinin ağırlıklı olarak gözlemlendiği bir alt bölge tanımladığı gözlenmektedir. Alanının kuzeyinde Kızlarağası Hanı ve çevresinde adaptasyon, direnç ve yerine geçme süreçlerinin gözlemlendiği söylemek mümkündür.

Parsel birleşmesi sonucu tek ada tek parsel şeklinde bir yapısal değişikliğin görüldüğü tek alt bölge olan "Il” numaralı bölge ise parsel bölünmeleri ve birleşmelerine bağlı yerine geçme süreçleri ile direnç evrelerinin gözlemlendiği alan olarak tespit edilmiştir. "I" ve "Il” numaralı bölgelerden yer alan han kullanımlarının işlevlerini kaybederek yerini ticaret kullanımına bıraktığı ve buna bağı olarak ihtiyaçlar doğrultusunda yapısal değişikliklere uğradıkları tespit edilmiştir. Çalışma alanının güneyinde yer alan "III" numaralı bölge ise adaptasyon sürecinin en yoğun, yapısal müdahalenin ise en az olduğu alan olarak dikkat çekmektedir. Çalışma alanının diğer bölgelerinde meydana gelen parsel değişim süreçlerine rastlanmayan "III” nu- maralı bölgenin, diğer bölgelere oranla karakteristik yapısını daha çok koruduğu söylenilebilir.

Eski Keresteciler Çarşısı örnek çalışma alanında yapılan incelemeler sonucunda, bütün bir sokak olma özelliğine sahip olsa da morfolojik süreçler yönünden farklı özellikler gösteren alt kısımlardan oluştuğu gözlemlenmiştir. Tarihsel süreç içerisinde ihtiyaçların ve buna bağlı olarak mekânın organizasyonunda birtakım değişikliklerin meydana geldiği görülmüştür. Kentsel mekânın değişimi esnasında, bu değişime karşı en az direnç gösteren fiziksel bileşenler hiç kuşkusuz binalar ve kullanımlardır. Örnek çalışma alanı kapsamında da değişimin temel olarak gözlemlendiği bileşenlerin de yapılar ve kullanımlar olduğu görülmüştür. Kullanıcının değişen ihtiyaçları doğrultusunda herhangi bir denetim, yönlendirme ya da gerekli koşullarda yaptırımın olmaması, değişen kullanımların yanında yapı ve parsellerin de değişimini beraberinde getirmiştir. Çalışma alanının kuzeyinde önceden depo olarak kullanılan yapıların günümüzde toptan ve perakende ticaret için kullanılması, yapıların ihtiyaç duyulmayan kısımlarının bireysel tadilatlar ile küçültülmesine; tam tersi 1905 döneminde konaklama faaliyetlerinin yer aldığı han yapılarının depo faaliyetleri için 
kullanılmak amacıyla iç duvarlarının yıkılarak genişletilmesine; tarihi doku içerisinde yer alan pasajların, sokağa bakan cephelerinin dokuya uygun olmayan yöntemlerle kapatılarak kullanım işlevinin değişmesine; cephe kaplamalarının modern malzemelerle, eski dokudan iz bırakmayacak şekilde kapatılmasına rastlanması Eski Keresteciler Çarşısındaki değişime verilebilecek örneklerden yalnızca bazılarıdır.

\section{Sonuç ve Değerlendirme}

Bu çalışmada değişen ihtiyaçlar çerçevesinde biçimlenen mevcut kent formunun hangi süreçlerden geçerek bu günkü halini aldığını ortaya koymayı amaçlayan bir çözümlemenin nasıl yapılacağı sorusundan yola çıkılmıştır. Bu kapsamda ele alınan literatür, kullanılan yöntem ve belirlenen örnek alanda yapılan incelemeler sonucunda, tarihi kent merkezlerindeki özgün dokunun korunması ve değişen ihtiyaçlar karşısında karakteristik değerlerinin modern çağın yapılaşma biçimlerine benzeyerek kentin diğer parçalarıyla aynılaşmaması için kentsel morfoloji ve tarihsel coğrafi yaklaşım kapsamındaki gelişme döngüleri analizlerinden yararlanılarak; korunması gerekli özgünlükler tespit edilebilir, değişen ihtiyaçlar karşısında tarihi kent merkezlerinin yeniden canlandırılması sürecinde kullanımların yer seçimine yönelik yaklaşım ve tasarımlar ile mekanın değişimi kontrol edilebilir. Tarihi kent merkezlerine yönelik hazırlanan koruma planları başta olmak üzere, kentsel dokunun mevcut ya da yeni parçalarına dair yapılan bütün plan çalışmalarında; mevcut kentsel karakterin ortaya konulması, özgün ve farklılaşan değerlerin tespit edilmesi ve bu değerlerin korunması amacıyla hangi stratejilerin geliştirilmesi gerektiği yönünde yapılan çalışmalara altlık olabilecek bir yöntem ortaya koyan kentsel morfoloji ve tarihsel coğrafi yaklaşım; tarihi kent dokusunun sürekliliği ve morfolojik yapısının iyi tanımlanması, işlevsel değişimin sürdürülebilir bir şekilde gerçekleşmesi için kısıtlı bir bakış açısının dışına çıkılması açısından önemlidir.

İzmir - Kemeraltı Tarihi Kent Merkezi - Eski Keresteciler Çarşısı'nda, 1905 yılından günümüze kadar olan süreçte meydana gelen morfolojik süreçlerin çözümlendiği bu çalışma kapsamında çalışma alanının benzer süreçlerin yaşandığı farklı alt bölgelerden meydana geldiği tespit edilmiştir. Kentsel mekânın değişimine yönelik yapılan gelişme döngüleri analizi kapsamında, çalışma alanının kuzey bölümünde inşa edildiği dönemde liman arkası depo faaliyetleri için kullanılan yapılarda; günümüzde ticaret kullanımının yer seçtiği ve bu değişim sürecinde alansal olarak ticaret kullanımı için çok büyük olan yapıların, herhangi bir denetim mekanizmasına takılmadan mekânsal ihtiyaçlar gereğince dönüşüme ve yapısal müdahaleye uğradıkları tespit edilmiştir. Yapının cephe aldığı sokağa paralel olacak şekilde ticaret kullanımı için gerekli olan alanın tutularak, kullanıcı için gereksiz olan kısmının bir iç duvar yardımıyla eskimeye terk edildiği ya da yapı adası boyunca olan parsellerin bölünerek yeni iki parselin ortaya çıktığı bu bölge; kentsel mekânın değişim sürecinde fiziksel ölçütlerin göz önüne alınmadan kullanımların yer seçmesine örnek gösterilebilir. Çalışma alanın orta kısmında yer alan bölge ise kuzeyde yer alan bölgeye benzer biçimde yerine geçme süreçlerinin gözlemlendiği ancak tarihi merkezin karakterini hiçe sayan yapısal özellikleri ve kullanımların yanı sıra, yerine geçme süreçlerine ek olarak direnç evresinin de gözlemlendiği bu bölgede; bölgenin özgün ve karakteristik dokusunun kaybolmaya başladığı görülmektedir. Çarşının güneyinde yer alan üçüncü ve son bölge ise; inşa edildiği dönemde zanaat kullanımlarının yerine, mekânsal açısından yapısal müdahale gerektirmeyen kullanımların gelmesi sebebiyle özgün dokunun en çok korunduğu bölgedir. Ancak bu bölgedeki koruma sürecinin de diğer iki alt bölgede olduğu gibi tesadüfi ve denetimden yoksun olarak, kendiliğinden geliştiğini söylemek mümkündür.

Toplumların ve kültürlerin sosyal yapısına dair izlerini, mekânsal ihtiyaçlarını, bu mekanların bir araya geliş biçimlerini, yapı tekniklerini, ustalık ve zanaat becerilerini kısacası geçmiş dönemlere ait kaybolmaya yüz tutmuş değerlerini barındıran tarihi kent merkezleri; modern toplumlar tarafından yeniden değerlendirilmesi (restore edilmesi, canlandırılması vb.), yönetilmesi ve korunması gereken kentsel dokulardır. Çalışma, tarihi ya da farklı kentsel alanlarda, kentsel mekânın değişiminin çözümlenmesini amaçlayan farklı araştırmalar için kavramsal bir çerçeve sunmasının yanı sıra değişim süreçlerinin yönetilmesine yönelik stratejilerin belirlenmesine yönelik bir yöntem ortaya koymaktadır. Özgün kentsel dokuların korunması ve mevcut doku ile uyumlu kullanımların yer seçim kararlarının verilebilmesi için formu meydana getiren süreçlerin ele alınması gerektiğini ortaya koyan çalışma; koruma ve kullanma stratejilerinin belirlenme sürecinde, akılcı yaklaşımların geliştirilmesine yönelik objektif bir başlangıç noktası geliştirilmesini mümkün kılmaktadır. Çalışma, Eski Keresteciler Çarşısı özelinde tek bir sokağın farklı alt bölgelerden oluştuğu, benzer bir çalışmanın tarihi merkezin tamamını kapsayacak şekilde geliştirilmesi ile alt bölge sayısının daha da artacağı kabulünden hareketle, ilk etapta bir bütün gibi düşünülen ve planlama çalışmaları kapsamında bütüne yönelik kararların verildiği tarihi kent merkezlerine yönelik koruma kararlarının detaylandırılmasına; kullanımların yer seçimine yönelik alınacak kararlarda, mevcut dokuya zarar vermeyen politikaların geliştirilmesine; kentsel mekânda meydana gelen değişimlerin hangi alanlarda nasıl yönetileceğine dair kararların alınması esnasında, kentsel mekâna özgü yaklaşımların geliştirilmesine katkı sağlamaktadır. 


\section{KAYNAKLAR}

Alexander, C. (1965). City Is Not A Tree. Architectural Forum, 58-62.

Arkon, H. (1978). Tarihi Kent Merkezinde Koruma Planlaması; İzmir Örneği Yüksek Lisans Tezi. İzmir.

Beyru, R. (2011). 19. Yüzyılda İzmir Kenti. Literatür Yayıncılık.

Conzen, M. (1960). Alnwick, Northumberland: A Study in Town-plan Analysis. London: Orge Philip \& Son Ltd.

Conzen, M. (1966). Historical Townscapes in Britain, A Problem in Applied Geography. Northern Geographical Essays, 56-78.

Conzen, M. (1975). Geography and Townscape Conservation. Giessener Geographische Schriften, Special Volume, 95-102.

Conzen, M. (1988). Morphogenesis, Morphological Regions and Secular Human Agency in The Historic Townscape as Examplified by Lodlow. G. S. Dietrich Denecke içinde, Urban historical geography: recent progress in Britain and Germany (s. 116-142). Cambridge: Cambridge University Press.

Cullen, G. (1961). Townscape. New York: Reinhold Publishing Corporation.

Friedmann, J. (2010). Place and Place-Making in Cities: A Global Perspective. Planning Theory and Practice 11(2), 149-165.

Jacobs, J. (1961). The Death and Life of Great American Cities. Random House.

Kropf, K. (1996). Urban Tissue and Character of Towns. Urban Design International, 1(3), 247-263.

Kropf, K. (2014). Ambiguity in the Definition of Urban Form. Journal of Urban Morphology, 18(1), 41-57.

Lynch, K. (1960). The Image of The City. Massachusetts Institute of Technology \& Harvard Collage.

Norberg-Schulz, C. (1979). Genius Loci: Towards a Phonomology of Architecture. New York: Rizzoli Internetional Publications.

Rossi, A. (1984). The Architecture of The City. Cambridge: The MIT Press.

Schlebusch, S. (2015). Planning for Sustainable Communities: Evaluating Place-Making Approaches. Architecture, Forestry and Fisheries Journal 4(4-1), 59-72.

Tuna, N. (1970). Kemeraltı Tarihsel Kentsel Sit Alanı Arazi Kullanış Haritası $1 / 1000$.

(2007). Urban Design Compendium. English Partnerships / The Housing Corporation / Llewelyn-Davies.

(2017). İzmir Tarih Projesi Tasarım Stratejisi Raporu. İzmir: İzmir Büyükşehir Belediyesi.

Whitehand, J. (1981). The Urban Landscape: Historical Development and Management Papers By M.R.G. Conzen. London: Academic Press INC. (London) LTD. 